\title{
Effect of IBA (Indole Butyric Acid) levels on the growth and rooting of different cutting types of Clerodendrum splendens
}

\author{
Abbas Jamal ${ }^{1 *}$, Gohar Ayub ${ }^{1}$, Ali Rahman ${ }^{1}$, Anwar Rashid ${ }^{1}$, Jawad Ali ${ }^{2}$ \\ and Muhammad Shahab ${ }^{3}$ \\ 1. Department of Horticulture, The University of Agriculture Peshawar, Pakistan \\ 2. University of Swabi, Khyber Pakhtunkhwa, Pakistan \\ 3. Department of Agronomia, Universidade Estadual de Londrina, Rodovia Celco Garcia Cid (PR 445), km 380, \\ P.O. Box 6001, ZIP 86051-990, Londrina, PR, Brazil \\ *Corresponding author's email: abbasjamal143@gmail.com \\ Citation \\ Abbas Jamal, Gohar Ayub, Ali Rahman, Anwar Rashid, Jawad Ali and Muhammad Shahab. Effect of IBA (Indole \\ Butyric Acid) levels on the growth and rooting of different cutting types of Clerodendrum splendens. Pure and \\ Applied Biology. Vol. 5, Issue 1, 2016, pp64-71. http://dx.doi.org/10.19045/bspab.2016.50009
}

\begin{tabular}{llll}
\hline \hline Received: 23/06/2015 & Revised: 07/12/2015 & Accepted: 16/12/2015 & Online First: 25/12/2015 \\
\hline
\end{tabular}

\section{Abstract}

An experiment to evaluate different IBA levels and cutting types for achieving growth and rooting of Clerodendrum splendens was studied at Ornamental Horticulture Nursery, Department of Horticulture, The University of Agriculture Peshawar, Pakistan during the year 2012. In the experiment two types of cuttings were used i.e. stem cuttings and root cuttings and were treated with 0,10, 20 and 30\% IBA. Cuttings were then planted in polythene bags crammed with the mixture of clay, FYM and sand with the ratio of 1:1:1. IBA with the level of $20 \%$ showed best results regarding number of leaves per plant (14.0), number of roots per plant (9.8), root diameter $(2.4 \mathrm{~mm})$ and survival percentage $(60.0 \%)$. A significant increase in sprout length $(29.1 \mathrm{~cm})$ and root length $(24.8 \mathrm{~cm})$ were observed in cuttings treated with $10 \%$ IBA level over the control. Among cuttings, stem cuttings gave good results in all parameters as compared to the root cuttings. Interaction revealed that stem cuttings proved superior when treated with $20 \%$ IBA followed by $10 \%$ IBA, while root cuttings did not need IBA for rooting and resultant growth as these cuttings rooted and grew well without IBA. Hence it is recommended that stem cuttings need IBA at the rate of $20 \%$, while root cuttings should be used without treating with IBA.

Keywords: IBA; Cuttings; Clerodendrum splendens

\section{Introduction}

Clerodendrum splendens is an ornamental flowering plant in the genus Clerodendrum of the family Lamiaceae, native to tropical Western Africa [1]. It is quick growing, vigorous and evergreen climber, commonly called as Flaming Glorybower, Usually growing up to a height of 4 meter. Leaves are large, lush green and arranged oppositely on stem. Flowers are bright red in color, borne in a large terminal or axillary corymbose clusters in winter months. It is grown in evenly moist organically rich, well-drained soil in full sun to partial shade and is propagated through layering, stem and root cuttings [2].

The discovery of auxins as plant growth regulating chemicals, its physiological 
effects and practical applications form an attracting story of horticultural research [3]. From these studies, the finding that auxins could stimulate adventitious roots in cuttings was a major breakthrough commercially for plant propagation [4]. Thimann and Koepfli [5] reported that the synthetic Indole-3Acetic Acid (IAA) has the capability of forming roots. They demonstrated its practical use in stimulating root formation on cuttings. In the same year, the growth regulators Indole-3-Butyric Acid (IBA) and 1-Naphthalene Acetic Acid (NAA) were shown to be more effective than IAA for rooting [6]. All the growth regulators are not equally suitable for rooting performances. Among the growth regulators Indole Butyric Acid is the most commonly and widely used to achieve high percentage of rooting success for the ornamental species [7]. Since IBA has a higher activity, a broader range of effective concentration without toxicity and it is effective in more plant species. Therefore IBA is used more frequently than NAA [8].

When propagation through cuttings becomes very difficult, treatments with growth regulators i.e. IBA are applied in optimum concentration to promote rooting in stem cutting. Activity of growth regulators depends upon the amount of synthetic hormone applied and a particular concentration of growth regulator may be more effective for initiation of root in stem cuttings. Hence, the present investigation was carried out in order to improve the rooting ability of cuttings of this difficult to root climber by using IBA (Indole Butyric Acid). Objectives of the study were to find out best level of IBA for growth and rooting of Clerodendrum splendens, to explore which cutting show better response to IBA and to find out best interaction between IBA and cuttings.

\section{Materials and methods}

An experiment entitled "Effect of IBA levels on the growth and rooting of different cutting types of Clerodendrum splendens" was conducted at Ornamental Nursery Farm, Department of Horticulture, The University of Agriculture, Peshawar during the year 2012. The experiment was laid out as RCBD (randomized complete block design) with split-plot arrangement. Stem cuttings and root cuttings of Clerodendrum splendens were assigned to main plot and levels of IBA were randomly assigned to sub plots. The experiment was replicated three times. The experiment included the following factors and their levels:

Cuttings: $\mathrm{C} 1=$ Stem Cuttings, $\mathrm{C} 2=$ Root Cuttings

IBA Levels: $\mathrm{T}_{0}=0 \%$ (Control), $\mathrm{T}_{1}=10 \%$, $\mathrm{T}_{2}=20 \%, \mathrm{~T}_{3}=30 \%$

Hardwood stem cuttings containing two buds were taken from healthy and vigorous growing Clerodendrum splendens plant. Slanting cuts were given to the stem cuttings just below the bud at the proximal end. In case of root cuttings, young, vigorous pencil thick roots close to the crown were selected. Any fibrous lateral roots were discarded. Each root was divided into $5 \mathrm{~cm}$ long cuttings. Required IBA levels, 0\%, 10\%, $20 \%$ and $30 \%$ were prepared by mixing IBA with Talc Powder. To prepare 10\% IBA, $50 \mathrm{mg}$ of IBA was mixed with $450 \mathrm{mg}$ of Talc Powder. $20 \%$ and $30 \%$ IBA were prepared accordingly. 0\% IBA contains only Talc Power. Root and stem cuttings were dipped in the mixture of IBA and Talc Powder. Polythene bags were filled with the planting media which was prepared from the combination of FYM, clay and sand at the ratio of $1: 1: 1$. There were 10 cuttings of each root and stem in each treatment with a total number of 80 cuttings in each replication that makes a total of 240 cuttings for the whole experiment. Cuttings were then planted in polythene bags. The whole 
experiment was covered in a plastic tunnel to keep the humidity level high in order to prevent the water loss from the cuttings.

Sprout length $(\mathrm{cm})$ and root length $(\mathrm{cm})$ of randomly selected plants for all treatments in each replication were measured with the help of measuring tape and then average was calculated. Average number of roots per cutting and leaves per cutting were recorded for all treatments in each replication. Root diameter $(\mathrm{mm})$ was measured by taking the thickness of the roots that emerged from the cutting with the help of vernier caliper and then mean was calculated and the percentage of survival of cuttings was calculated with the help of the following formula:

Plant Survival \%age $=$

Total No. of survived cuttings x 100

Total No. of sprouted cuttings

\section{Statistical Analysis}

Least significant difference (LSD) test was used for the mean comparison. The recorded data collected on each parameter was subjected to analysis of variance (ANOVA) in order to observe the difference between treatments as well as their interaction. For calculating both LSD and ANOVA, computer statistical software MSTATC was applied [9].

Results and Discussions

Sprout length $(\mathrm{cm})$
Mean data regarding sprout length are described in Table 1. Analysis of variance showed that IBA had significant effect on sprout length and the interaction between cutting types and IBA was also significant.

From the mean values of mean table of sprout length, it revealed that highest sprout length (29.1) was recorded in cuttings treated with $10 \%$ IBA followed by $20 \%$ (27.8) and 30\% IBA (23.2) respectively. Whereas minimum sprout length (23.1) was noticed in cutting treated with no IBA. Stem cuttings showed better result (35.0) as compare to the root cuttings (16.7). In interaction, maximum sprout length (41.3) was noticed in stem cutting at $10 \%$ IBA, on the other hand root cuttings showed minimum sprout length (15.0) at $30 \%$ IBA level. By increasing IBA levels in root cuttings, sprout length decreases this is because root cells are significantly more sensitive to auxin concentrations as compare to the cells of the shoot [10]. The increase in sprout length in stem cuttings is related with rooting. Cuttings treated with IBA gave more rooting which helped in more nutrient uptake and ultimately increased the sprout length. These findings are in accordance with the results of Hussain and Khan [11] who achieved tallest plants and longer roots in two Rosa species by treatment with IBA.

Table 1. Mean table for sprout length of cutting types as affected by IBA levels

\begin{tabular}{|c|c|c|c|}
\hline \multirow[b]{2}{*}{ IBA levels (\%) } & \multicolumn{2}{|c|}{ Cutting types } & \multirow[b]{2}{*}{ Means } \\
\hline & Stem & Root & \\
\hline 0 & 27.4 & 18.9 & $23.1 \mathrm{c}$ \\
\hline 10 & 41.3 & 17.0 & $29.1 \mathrm{a}$ \\
\hline 20 & 39.8 & 15.8 & $27.8 b$ \\
\hline 30 & 31.4 & 15.0 & $23.2 \mathrm{c}$ \\
\hline Means & $35.0 \mathrm{a}$ & $16.7 \mathrm{~b}$ & \\
\hline
\end{tabular}




\section{Root Length (cm)}

The mean data regarding root length are presented in mean Table 2. The ANOVA table showed that the length of root is significantly affected by IBA at different levels, while interaction between cuttings type and IBA had also shown a significant effect on the length of root of Clerodendrum splendens cuttings. Mean values shows that maximum root length (24.8) was noticed in cuttings at concentration of $10 \%$ IBA while minimum root length (19.4) was recorded in control. In different cutting types stem cuttings showed better result (30.3) as compare to the root cuttings (13.3). Specific trend was observed so far in interaction.
Longest roots (34.6) were observed at $10 \%$ IBA in stem cutting, while root cuttings showed poor result (10.8) at 30\% IBA.

The above results might be due to the reason that the sprouted cuttings were having high foliage and leaves are the main site of food production which is translocated to the roots for development. On the other hand, IBA helped the roots to grow deeper in the soil for locating more nutrients and thus resulted in increased root length. These results are in partial agreement with Hussain and Khan [11] who reported that IBA produced significantly longer roots and maximum root percentage in Rosa species than control.

Table 2. Mean values for root length of cutting types as affected by IBA levels

\begin{tabular}{c|cc|c}
\hline \multirow{3}{*}{ IBA levels } & \multicolumn{2}{|c|}{ Cutting types } & \multirow{2}{*}{ Means } \\
\cline { 2 - 3 } & Stem & Root & $20.2 \mathrm{c}$ \\
0 & 25.0 & 15.5 & $24.8 \mathrm{a}$ \\
20 & 34.6 & 15.1 & $22.7 \mathrm{~b}$ \\
30 & 33.7 & 11.7 & $19.4 \mathrm{c}$ \\
\hline & 28.0 & 10.8 & \\
\hline
\end{tabular}

LSD value for Cuttings (C) at $5 \%$ level of probability $=1.228963$

LSD value for IBA (I) at $5 \%$ level of Probability $=2.00454$

LSD value for $\mathrm{C} x \mathrm{I}$ at $5 \%$ level of probability $=2.834847$

\section{Number of leaves per plant}

The data pertaining to the number of leaves per plant are presented in Table 3.On the basis of Analysis of variance, number of leaves per plant was significantly affected by various concentrations of Indole Butyric Acid, while types of cuttings and their interaction had also a significant effect.

It is evident from the results that maximum number of leaves per plant (14.0) was observed on cuttings which were treated with $20 \%$ IBA, followed by $10 \%$ IBA (12.3) and $0 \%$ IBA (12.0). Minimum number of leaves per plant (10.6) was recorded in cuttings treated with $30 \%$ IBA. The mean value for the cutting types showed that maximum number of leaves (15.1) were noted in stem cutting as compare to the root cuttings (9.4). This is because the root cuttings took more than 40 days to sprout as compare to the stem cuttings which sprouted in about two weeks. In interaction more no. of leaves (18.6) were produced in stem cutting treated with $20 \%$ IBA, while root cuttings showed less number of leaves (6.9) at $30 \%$ IBA level.

The increase in number of leaves on $20 \%$ IBA concentration may be due to more number of roots which resulted in increased plant height and subsequently branches per plant. These results are partial in agreement with Siddiqui and Hussian [12] who reported that after treatment of Ficus hawaii 
cuttings with IBA produced more no. of leaves. Bhattacharjee and Balakrishna [13] also conducted an experiment on several ornamental climbers including
Clerodendrum splendens and noticed that by dipping the stem cuttings in IBA solutions can increase the rooting and the number of leaves in the cuttings.

Table 3. Mean table for number of leaves per plant of cutting types as affected by IBA levels

\begin{tabular}{c|cc|c}
\hline \multirow{2}{*}{ IBA levels (\%) } & \multicolumn{2}{|c|}{ Cutting Types } & \multirow{2}{*}{ Means } \\
\cline { 2 - 3 } & Stem & Root & $12.0 \mathrm{~b}$ \\
10 & 13.3 & 10.7 & $12.3 \mathrm{~b}$ \\
20 & 14.1 & 10.5 & $14.0 \mathrm{a}$ \\
30 & 18.6 & 9.4 & $10.6 \mathrm{c}$ \\
\hline Means & 14.4 & 6.9 & \\
\hline
\end{tabular}

LSD value for Cuttings (C) at $5 \%$ level of probability $=1.309794$

LSD value for IBA (I) at $5 \%$ level of probability $=1.562742$

LSD value for $\mathrm{C} \mathrm{x}$ I at $5 \%$ level of probability $=2.210051$

\section{Number of roots per plant}

The data regarding number of roots per plant is presented in table 4. According to ANOVA, IBA levels and its interaction had significant effect on number of roots per plant. More number of roots per plant (9.8) occurred with IBA at the concentration of $20 \%$ followed by $10 \%$ IBA (8.8) and $30 \%$ IBA (7.6) whereas at 0\% IBA plants produced least number of roots per plant (7.1). In case of cutting types more number of roots per plant (10.6) were recorded in stem cuttings. Minimum number of roots per plant (6.6) in root cuttings were also noticed. As already mentioned that there was a significant interaction between cutting types and IBA levels, Stem cuttings at 20\% IBA level produced maximum number of roots per plant (12.6) while minimum number of roots (5.8) were observed in root cuttings with at the rate of $30 \%$. The poor results regarding root cuttings was due to the sensitivity of root cells toward IBA levels as compare to shoot cells. So roots cannot tolerate high concentrations of auxin [10].

These results are in conformity with the results of Bhattacharjee and Balakrishna [13] who noticed that dipping the stem cuttings of Clerodendrum splendens in IBA solutions (1000-6000ppm) improved the number of roots.

Table 4. Mean table for number of roots per plant of cutting types as affected by IBA levels

\begin{tabular}{c|cc|c}
\hline \multirow{2}{*}{ IBA levels $(\%)$} & \multicolumn{2}{|c|}{ Cutting Types } & \multirow{2}{*}{ Means } \\
\cline { 2 - 3 } & Stem & Root & $7.1 \mathrm{c}$ \\
10 & 8.3 & 6.0 & $8.8 \mathrm{~b}$ \\
20 & 9.8 & 7.8 & $9.8 \mathrm{a}$ \\
30 & 12.6 & 7.0 & $7.6 \mathrm{c}$ \\
\hline Means & 9.4 & 5.8 & \\
\hline
\end{tabular}

LSD value for Cuttings (C) at 5\% level of probability $=1.842436$

LSD value for IBA (I) at 5\% level of Probability $=0.862316$

LSD value for C x I at 5\% level of probability $=1.219499$ 


\section{Root Diameter (mm)}

The data pertaining to the root diameters are presented in Table 5. ANOVA showed that root diameter is significantly affected by IBA levels, as well as the interaction between cutting types and IBA was also significant. Maximum root diameter (2.4) was observed with IBA at $20 \%$, followed by $10 \%$ and $30 \%$ (2.3), (2.2) whereas cuttings in control produced roots with minimum diameter (2.1). By comparing cutting types, stem cuttings produced roots with maximum diameter (2.5) as compare to the root cuttings (2.0). In interaction linear relationship was observed, stem cuttings at $20 \%$ IBA level showed best results (2.8) regarding the diameter of root, while poor results in root cuttings (1.8) was observed with $30 \%$ IBA. This may due to the inhibitory or toxic effect of IBA at higher concentration [14].

These current results are also in positive relation with Singh and Singh [15] who also observed maximum root diameter in Clerodendrum thomsoniae cuttings when treated with

IBA.

Table 5. Mean table for root diameter of cutting types as affected by IBA levels

\begin{tabular}{c|cc|c}
\hline \multirow{2}{*}{ IBA levels (\%) } & \multicolumn{2}{|c|}{ Cuttings type } & \multirow{2}{*}{ Means } \\
\cline { 2 - 3 } & Stem & Root & $2.1 \mathrm{c}$ \\
0 & 2.2 & 2.0 & $2.3 \mathrm{ab}$ \\
20 & 2.4 & 2.2 & $2.4 \mathrm{a}$ \\
30 & 2.8 & 2.0 & $2.2 \mathrm{bc}$ \\
\hline Means & 2.5 & 1.8 & \\
\hline
\end{tabular}

LSD value for Cuttings (C) at $5 \%$ level of probability $=0.224462$

LSD value for IBA (I) at $5 \%$ level of Probability $=0.134532$

LSD value for $\mathrm{C} x \mathrm{I}$ at $5 \%$ level of probability $=10.190257$

\section{Survival percentage}

The data pertaining to the percentage of survival are presented in Table 6, the analysis of variance for IBA levels and cutting types showed highly significant effect on survival percentage of sprouted cuttings. And their interaction was also significant. According to the mean value, lowest survival percentage (46.7\%) was recorded in cuttings treated at $30 \%$ IBA level while best survival percentage $(60 \%)$ was noted in cuttings treated with IBA at $20 \%$ concentration. Comparing different types of cuttings, maximum survival percentage $(57.2 \%)$ was observed in stem cuttings followed by root cuttings (47.5\%). The interaction revealed that the stem cuttings showed best result (73.3\%) regarding survival percentage at $20 \%$ IBA,
In case of root cuttings minimum survival percentage $(40 \%)$ was noted at $30 \%$ IBA.

Maximum percentage of survival at $20 \%$ IBA may be due to the reason that IBA enhanced lengthy roots which subsequently increased the number of leaves per plant. Nutrients uptake and photosynthates production provides sufficient food contents for the metabolic activities of the plants. These results are in accordance with Ahmad et al. [16] who reported that the Bougainvillea cuttings when treated with IBA showed maximum survival percentage. Root cutting shows good result at $0 \%$ IBA due to the fact that root cells are more sensitive and showed inhibitory effect to the synthetic auxin. These results in root cuttings are also in accordance withCampagnolo and Rafael [17] who concluded best survival percentage in the root cuttings of blackberries at $0 \%$ IBA. 
Table 6. Mean table for survival percentage of cutting types as affected by IBA levels

\begin{tabular}{c|cc|c}
\hline \multirow{2}{*}{ IBA levels } & \multicolumn{2}{|c|}{ Cutting types } & \multirow{2}{*}{ Means } \\
\cline { 2 - 3 } & Stem & Root & $50.0 \mathrm{~b}$ \\
0 & 43.3 & 56.7 & $53.3 \mathrm{ab}$ \\
$20 \%$ & 60.0 & 46.7 & $60.0 \mathrm{a}$ \\
$30 \%$ & 73.3 & 46.7 & $46.7 \mathrm{~b}$ \\
\hline Means & 53.3 & 40.0 & \\
\hline
\end{tabular}

LSD value for Cuttings (C) at 5\% level of probability $=6.210344$

LSD value for IBA (I) at 5\% level of Probability $=8.516282$

LSD value for $\mathrm{C} x \mathrm{I}$ at $5 \%$ level of probability $=12.04384$

\section{Conclusion}

The following conclusions were drawn from the findings of above experiment. IBA level of $20 \%$ showed best results regarding, number of leaves per plant, number of roots per plant, root diameter and survival percentage. Sprout length and root length were best recorded at IBA level of $10 \%$.

Stem cuttings showed good result at $20 \%$ IBA followed by $10 \%$ IBA in almost all parameters. Root cuttings showed better result without IBA.

\section{Recommendations}

The following recommendations are drawn from the study for future. Since IBA level at $20 \%$ has shown best results regarding rooting and growth, therefore it is recommended for Stem cuttings of Clerodendrum splendens. It is also recommended that root cuttings may not be treated with IBA. However, further research to narrow the intervals of IBA levels $(10,15$, 20 and 25\%) should be carried out on Stem cuttings of Clerodendrum splendens.

\section{Authors' contributions}

Conceived and designed the experiments: $\mathrm{G}$ Ayub, Performed the experiments: A Jamal \& M Shahab, Analyzed the data: A Jamal, A Rahman, J Ali, G Ayub, A Rashid \& M Shahab, Contributed reagents/ materials/ analysis tools: A Rashid \& M Shahab, Wrote the paper: A Jamal \& G Ayub.

\section{Acknowledgements}

I have no words to express my deepest sense of gratitude to Allah Almighty, the most Merciful, and the Beneficent. Who bestowed upon me the courage to complete this project, and contribute to the noble field of knowledge and cordial gratitude to the Prophet Muhammad (P.B.U.H) who is forever a torch of guidance and knowledge for humanity.

I wish to express my deepest gratitude and profound regard to my honorable and great supervisors the late Prof. Dr. Muhammad Zubair and Prof. Dr. Gohar Ayub, Department of Horticulture, The University of Agriculture, Peshawar for their constant encouragement, helpful suggestions and guidance during my scholastic life. Their critical insight, consistent advice, constructive criticism, personal interest and supervision, generated the vigor in me to complete this research project. Special thanks are extended to Prof. Dr Abdur Rab Chairman, Department of Horticulture, The University of Agriculture Peshawar, for his kind behavior, scholastic guidance.

I feel pleasure to thank members of my supervisory committee, Dr. Sajid Department of Horticulture and Dr. Amanullah Jan, Department of Agronomy. The University of Agriculture, Peshawar. I would also like to thank my friends Muhammad Shahab, Ali Rahman, Jawad Ali, Anwar Rashid and Khaleeq Ur Rahman 
who supported me during my research project.

Last but not least, I would like to thank all my family particularly loving Mother and understanding being constant source of prayers and inspiration which enabled me to complete my M. Sc. (Hons) work successfully. Words are meaningless what they have given me. May Allah give me the strength to serve them to my best; Ameen.

\section{References}

1. RHS (2008). A-Z encyclopedia of garden plants. United Kingdom: Dorling Kinderdley pp: 1136.

2. Vinaykumar J, Shirol AM, Kulkarni BS, Krishnamurthy GH \& Keddy BS (2007). Effect of growth regulators on rooting of Arribidaea magnifica and Clerodendrum splendens. Karnakata j Agric Sci 21(2): 320-321.

3. Tincker MAH (1936). The relation of growth substances or hormones to horticultural practice. J Royal Hort Society 61(2): 380-388.

4. Arteca RN (1996). Plant Growth Substances: Principles and Applications. Chapman and Hall, New York: pp 23-31.

5. Thimann KV \& Koepfli JB (1935). Identity of the growth promoting and root forming substances of plants. Nature 135(1): 101-102.

6. Zimmerman PW \& Wilcoxon F (1935). Several chemical growth substances which cause initiation of roots and other responses in plants. Contrib Boyce Thomp Inst 7(3): 209-229.

7. Kundu UK, Farooque AM, Aditya DK \& Mondal MF (1987). Effect of IBA on propagation of Ixora coccinia by stem cutting. Bangladesh Hort 15(2): 7-10.

8. Hartmann HT \& Kester DE (1968). Plant propagation principles 3rd Ed, Englewood Cliffs, NJ Prentice Hall INC.
9. Steel RGD \& Torrie JH (1980). Analysis of covariance, In: Principles and procedures of statistics: a biometrical approach. McGraw-Hill New York pp: 401-437.

10. Thimann KV (1937). On the nature of inhibitions caused by auxin. American $J$ Botany 24: 407-412.

11. Hussain A \& Khan MA (2004). Effect of growth regulators on stem cuttings of Rosa bourboniana. Int J Agric Biol 6(5): 931-932.

12. Siddiqui MI \& Hussian SA (2002). Effect of indole butyric acid and types of cutting on root initiation of Ficus hawaii. Sarhad J Agric 23(4): 919-926.

13. Bhattacharjee SK \& Balakrishna M (1990). Studies on rooting behavior of stem cutting of woody ornamental climbers. South Ind Hort 38: 112-114.

14. Giddaplavar MS (1988). Propagation studies in ornamental climbers by cuttings. Karnakata J Agric Sci 21(2): 321

15. Singh AK \& Singh NP (2000). Effect of auxins on regeneration of Clerodendron thomsonae stem cutting. Indian J Hill Farming 13(1): 58-61.

16. Ahmad N, Ishtiaq M \& Nabi G (2002). Influence of various concentrations of indole butyric acid (IBA) on different types of Bougainvillea glabra var. variegata cuttings. Sarhad J Agric 18(3): 263-270.

17. Campagnolo MA \& Rafael P (2012). Rooting of stems and root cutting of blackberry cultivars collected in different times, cold storage and treatment with IBA. Cienc Rural 42(2): 232-237. 